\title{
Xylocarpus Moluccensis Induces Cytotoxicity in Human Hepatocellular Carcinoma HepG2 Cell Line via Activation of the Extrinsic Pathway
}

\author{
Gul-e-Saba Chaudhry ${ }^{1 *}$, Nur Khairina Ahmed Sohimi', Habsah Mohamad ${ }^{1}$, \\ Muhammad Naveed Zafar ${ }^{2}$, Aziz Ahmed ${ }^{3}$, Yeong Yik Sung1, Tengku Sifzizul \\ Tengku Muhammad ${ }^{1 *}$
}

\begin{abstract}
Objective: Liver cancer is one of the most common causes of cancer death, with reduced survival rates. The development of new chemotherapeutic agents is essential to find effective cytotoxic drugs that give minimum side effects to the surrounding healthy tissues. The main objective of the present study was to evaluate the cytotoxic effects and mechanism of cell death induced by the crude and diethyl ether extract of Xylocarpus mouccensis on the human hepatocellular carcinoma cell line. Methods: The cytotoxicity activity was measured using the MTS assay. The mode of cell death determined by the apoptosis study, DNA fragmentation analysis done by using the TUNEL system. The pathway study or mechanism of apoptosis observed by study caspases 8, 9, 3/7 Glo-caspases method. Results: In this study, the methanol extracts prepared from leaf Xylocarpus mouccensis leaf produced cytotoxicity effect with $\mathrm{IC}_{50}(72 \mathrm{hr})$ $<30 \mu \mathrm{g} / \mathrm{ml}$. The $\mathrm{IC}_{50}$ value at 72 hours exerted by diethyl ether extract of Xylocarpus moluccensis leaf was $0.22 \mu \mathrm{g} / \mathrm{ml}$, which was more cytotoxic than to that of crude methanol extract. The results obtained by the colorimetric TUNEL system suggest that methanol crude extract of Xylocarpus moluccensis (leaf), diethyl ether extract of Xylocarpus moluccensis (leaf) and methanol extract of Xylocarpus granatum (bark) induced DNA fragmentation in the HepG2 cell line. Besides, the caspase-Glo assay demonstrated that diethyl ether leaf extract of Xylocarpus moluccensis triggered apoptotic cell death via activation of caspases -8 , and $-3 / 7$ However, no visible activation was noticed for caspase -9 . Furthermore, TLC indicates the presence of potential metabolites in an extract of Xylocarpus moluccensis. Conclusion: Thus, the present study suggests the remarkable potential of active metabolites in the extract of Xylocarpus moluccensis as a future therapeutic agent for the treatment of cancer.
\end{abstract}

Keywords: Apoptosis- cytotoxicity- DNA fragmentation- extrinsic pathway-HepG2- Mangroves-Xylocarpus moluccensis

Asian Pac J Cancer Prev, 22, Anticancer Activity of Natural Compounds: HOW's on Methods and Reports Suppl, 17-24

\section{Introduction}

Cancer is one of the significant causes of death around the world. Despite the progress in cancer treatment, cancer continues to affect patients and is the leading cause of death worldwide. There is still a need for finding a solution to cure the complex disease, especially for aggressive and metastasized cancer (Chaudhry et al., 2020b; Chaudhry et al., 2019b; Nithya et al., 2014; Mou et al., 2011). Liver cancer is the second leading cause of global cancer death 788,000 mortality (Ferlay et al., 2015). About $90 \%$ of primary liver cancer is hepatocellular carcinoma (HCC) Treatment for advanced liver cancer may involve chemotherapy, radiation therapy, or both (Kleinsmith, 2007). During chemotherapy treatment, the liver is supplied with cytotoxic drugs directly to the fiver and kills the cancer cells. Many drugs in chemotherapy treatment are plant-derived anticancer compounds (Valli et al., 2012; Cragg and Newman, 2005). Natural compounds derived from a variety of medicinal plants led to the development of anticancer drugs with reduced adverse side effects (Desai et al., 2008). Many studies demonstrated the existence of compounds in traditional herbs that can inhibit cancer growth.

Mangroves trees have been used in traditional medicinal practice as they show healing properties on various diseases. Previous studies show that the methanolic extract of Xylocarpus moluccensis exhibited Cytotoxicity on gastric and breast ductal carcinoma cells (Uddin et al., 2011). The biologically active compounds;

${ }^{1}$ Institute of Marine Biotechnology, Universiti Malaysia Terengganu, 21030 Terengganu, Malaysia. ${ }^{2}$ Department of Chemistry, Quaid-i-Azam University, Islamabad, 45320, Pakistan. ${ }^{3}$ School of Fundamental Science, Universiti Malaysia Terengganu, 21030 Kuala Nerus, Terengganu, Malaysia.*For Correspondence: sababiochem@gmail.com, sifzizul@umt.edu.my 
limonoids, gedunin, and la-hydroxy-1,2-dihydrogedunin isolated from the tree bark of Xylocarpus granatum of Bangladeshi Sundarban were reported to exhibit cytotoxicity effects toward cancer cells, in vitro (Uddin et al., 2007, Wangensteen et al., 2006).

The cancer cell typically involves two distinct forms of cell death; Apoptosis and necrosis. (Jan and Chaudhry, 2019). Necrosis is generally known as the 'accidental cell death caused by severe physical or chemical interruption, and physiologically shows severe inflammatory responses (Kaloger, 2012). Apoptosis is the "normal cell death by suicide that removes unwanted or useless cells, causes no inflammatory responses (Fuchs and Steller, 2011). Apoptosis is control by different groups of the executioner and regulatory molecules (Mukhopadhyay et al., 2014). A series of biochemical events include; activation of caspases, cytochrome c release, phosphatidylserine externalization, and fragmentation of internucleosomal DNA (Jan and Chaudhry, 2019). Biochemical alterations include DNA fragmentation and activation of cysteine aspartyl proteases, called caspases, which leads to the destruction of the cell (Nikoletopoulou et al., 2013). Caspases are central in apoptosis for the induction of apoptosis by individual effectors (Li and Yuan, 2008). Therefore, the significant caspases study done to reveal the pathway of apoptosis events. The present study conducted to determine the of the Xylocarpus molucconsis induce Cytotoxicity and mode of cell death in (HepG2) cell line.

\section{Materials and Methods}

\section{Materials}

Human hepatocellular carcinoma cell line (HepG2) purchased from American Type Cell Culture, USA. Roswell Park Memorial Institute (RPMI) 1640 medium was purchased from Nacalai Tesque, Japan. Penicillin-streptomycin solution, Fetal Bovine Serum (FBS), and other cell culture supplies obtained from Gibco, USA. CellTiter 96TM Aqueous Non-Radioactive Cell Proliferation Assay kit (MTS), Calorimetric Apoptosis Detection Kit (TUNEL), and Caspases-GloTM kit $-3 / 7,8$ and 9 purchased from Promega, USA. All other chemical solvents purchased from Merck, Germany.

\section{Preparation of extracts and partition extracts}

The mangrove plants (Xylocarpus moluccensis) collected from Umbai, Malacca. Xylocarpus granatum leaves obtained from Umbai, Malacca GPS coordinates (N 02 09'. 330"), stem bark and root GPS coordinates (E 102²0’.192”). Xylocarpus moluccensis leaves collected from Umbai, Malacca GPS coordinates (N $\left.02^{\circ} 09^{\prime} .335^{\prime \prime}\right)$ stem bark and root GPS coordinates (E $\left.102^{\circ} 20^{\prime} .175^{\prime \prime}\right)$. The specimens deposited in the Institute of Marine Biotechnology, UMT, Malaysia. The leaves were freeze-dried and ground to powdered form by using the mechanical grinder. The methanol extract prepared by using our previously reported cold extraction techniques (Gul-e-Saba et al., 2018). The extraction carried using a cold extraction technique where $10 \mathrm{~g}$ of the powdered samples exhaustively soaked in $100 \mathrm{ml}$ methanol for 15 minutes. The soaking process repeated until the extract became colorless, indicating that most of the compounds extracted out. The extracts filtered through Whatman's No. 1 filter paper. The solvent dried under reduced pressure by using a rotary evaporator at $30-35^{\circ} \mathrm{C}$. Furthermore, four extracts, methanol, diethyl ether, butanol, and aqueous extract used in this study.

\section{Cytotoxicity study by using MTS assay}

CellTiter 96TM Aqueous Non-Radioactive Cell Proliferation Assay (MTS assay) was used to evaluate the cytotoxicity activity of extract on the HepG2 cell line (Hudaya et al., 2017; Chaudhry GS et al., 2020a; Chaudhry GS et al., 2020c). The human hepatocellular carcinoma cell line, HepG2, was cultured in complete medium (RPMI), supplemented with 10\% (v/v) fetal bovine serum (FBS), 1\% (v/v) essential amino acid, 1\% (v/v) sodium pyruvate, and $1 \%(\mathrm{v} / \mathrm{v})$ of antibiotic solution, penicillin-streptomycin. For the negative control, the cells treated with $1 \%(\mathrm{v} / \mathrm{v})$ DMSO without extracts. Vincristine sulfate (Sigma, USA) used as positive control (Song et al., 2008). After that, CellTiter 96TMAQueous Solution Reagent $(20 \mu \mathrm{l})$ was added into each well for $3 \mathrm{hr}$ at $37^{\circ} \mathrm{C}$. Finally, the absorbance recorded using ELISA 96-well plate reader at $490 \mathrm{~nm}$.

\section{Determination of apoptotic cell death (DNA fragmentation) by TUNEL assay}

The Terminal deoxynucleotidyl transferase UTP nick end labeling (TUNEL) assay used to study DNA fragmentation in HepG2 cells. The cells were cultured in the labtek chamber slides at a cell density of $2 \times 10^{4}$ cells/ chamber and incubated at $37^{\circ} \mathrm{C}$ in a humidified atmosphere in the presence of $5 \%(\mathrm{v} / \mathrm{v}) \mathrm{CO}_{2}$ for $24 \mathrm{hr}$. As previously reported (Chaudhry et al., 2019a; Zafar et al., 2019; Mahar et al., 2019) with slight modifications as in this study, the colorimetric reagent used. After treatment, the cells fixed by using $4 \%$ paraformaldehyde solution in PBS ( $\mathrm{pH} 7.4$ ) for 25 mins at $4{ }^{\circ} \mathrm{C}$. The fixed cells then permeabilized by immersing the slides in $0.2 \%(\mathrm{v} / \mathrm{v})$ Triton X-100 solution (prepared in PBS). For negative control, the cells treated with $1 \%(\mathrm{v} / \mathrm{v})$ DMSO. The slides were mounted with DPX mounting medium and allowed to dry overnight. The slides observed under the light microscope and the images captured.

\section{Caspase assay}

The levels of active caspases-3/7, $-8,-9$ were determined by using Caspase Glo ${ }^{\mathrm{TM}}$ Assay (Promega, USA) (Chaudhry et al., 2019b). Human hepatocellular carcinoma cell line, HepG2 was treated with extracts at a concentration of $\mathrm{IC}_{50}(72 \mathrm{hr})$. The cells were incubated for different time points $(0 \mathrm{hr}, 1 \mathrm{hr}, 3 \mathrm{hr}, 6 \mathrm{hr}, 9 \mathrm{hr}, 12 \mathrm{hr}, 15 \mathrm{hr}$, $18 \mathrm{hr}, 21 \mathrm{hr}, 24 \mathrm{hr}, 27 \mathrm{hr}$, and $30 \mathrm{hr}$ ) at $37^{\circ} \mathrm{C}$ in a humidified atmosphere in the presence of $5 \%(\mathrm{v} / \mathrm{v}) \mathrm{CO}_{2}$. MG-132 inhibitor added to reduce non-specific background activity and mixed thoroughly. The method was according to the manufacturer's protocol. For negative control, the cells treated with $1 \%(\mathrm{v} / \mathrm{v})$ DMSO. The luminescence of each sample was measured and recorded using a luminometer. 
Phytochemical screening and TLC chromatography

TLC analysis was performed on TLC silica gel 60 F254 plates to identify the presence of active compounds in the Xylocarpus moluccensis leave diethyl ether, butanol, and aqueous extracts. The fractions and standard compounds were diluted in a requisite amount of solvent and spotted on the TLC plate. TLC plate then developed using solvent system hexane: ethyl acetate: ethanol (6:3:1) for diethyl ether extract, methanol: water (8:2) for butanol extract and methanol: water $(7: 3)$ for aqueous extract. After development, the TLC plate visualized under UV$254 \mathrm{~nm}, \mathrm{UV}-365 \mathrm{~nm}$ and, as well as the vanillin-sulphuric acid reagent to confirm the presence of active compounds in extracts.

\section{Statistical analysis}

All experiments performed in three replicates, and the results computed as mean \pm standard deviation. ANOVA (one-way) and Dunnet post-test showed using SPSS 16.0.

\section{Results}

Cytotoxicity effects of methanol and partition extracts of Xylocarpus moluccensis on HepG2 cells

The in vitro cytotoxicity of the methanol extracts of
Table 1. $\mathrm{IC}_{50}$ Values of Xylocarpus moluccensis Extract

\begin{tabular}{llc}
\hline Plant species & Plant parts & $\begin{array}{c}\text { Cytotoxicity effects } \\
\mathrm{IC}_{50}(\mu \mathrm{g} / \mathrm{ml})\end{array}$ \\
\hline Xylocarpus & Leaf & 25.12 \\
moluccensis & Bark & 74.13 \\
& Root & $>100$ \\
Xylocarpus & Leaf -Diethyl ether & 0.22 \\
moluccensis & Butanol & $>100$ \\
& Aqueous & $>100$ \\
\hline
\end{tabular}

Xylocarpus moluccensis on HepG2 studied. This study demonstrated that methanol extracts prepared from leaf and bark of Xylocarpus moluccensis produced inhibitory effects of more than $50 \%$ of the cell population when used to treat HepG2 cell line for 72 hours. However, root methanol extract from the same mangrove species did not inhibit more than $50 \%$ of the total cell population even though at the highest concentration $(100 \mu \mathrm{g} / \mathrm{ml})$ (Figure 1). Interestingly, the significant inhibitory effect was observed at low concentration $(3.13 \mu \mathrm{g} / \mathrm{ml})$ and steadily increased in a dose-dependent manner until $100 \mu \mathrm{g} / \mathrm{ml}$. However, bark extract only showed a significant cytotoxicity effect at concentrations $50 \mu \mathrm{g} / \mathrm{ml}$ and higher.

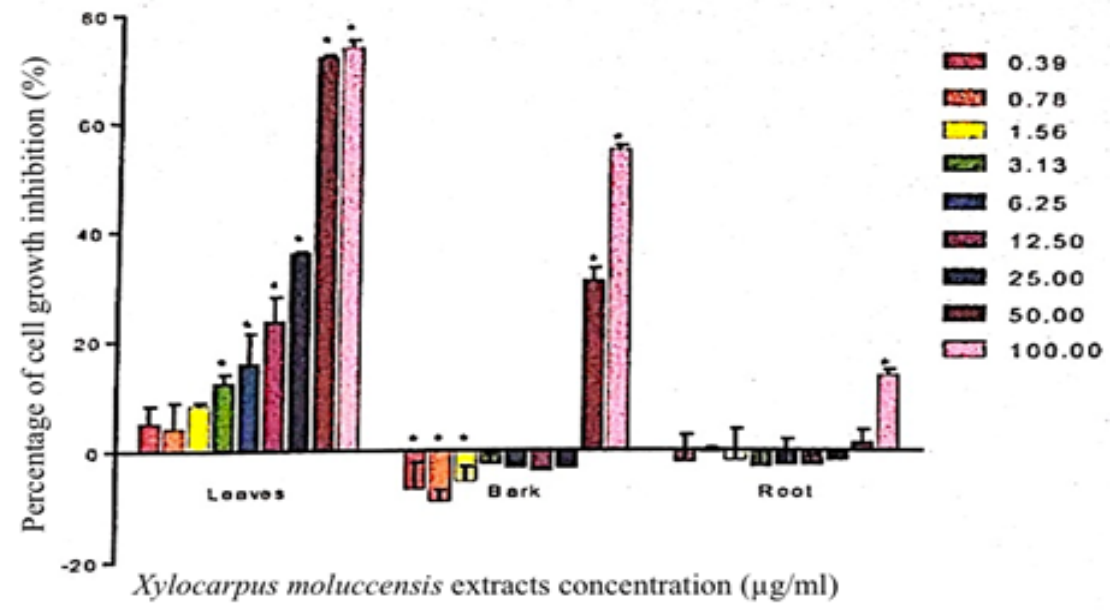

Figure 1. Cytotoxic Effects of Xylocarpus moluccensis Extracts on the HepG2 Cell Line Using MTS Assay

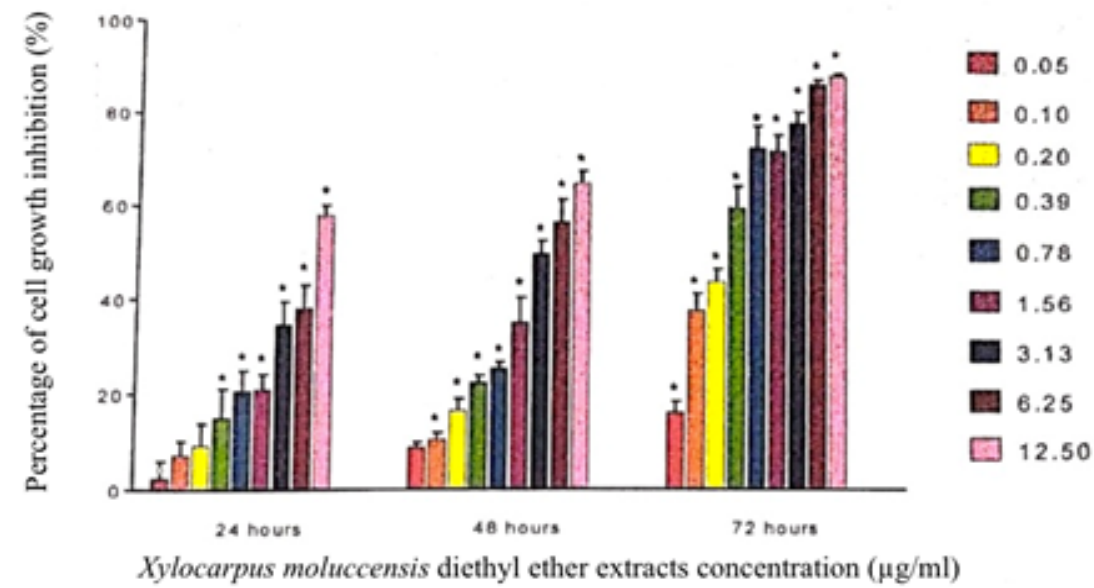

Figure 2. Cytotoxic Effects of Xylocarpus moluccensis Diethyl ether Extract on HepG2 Cell Line Using MTS Assay 


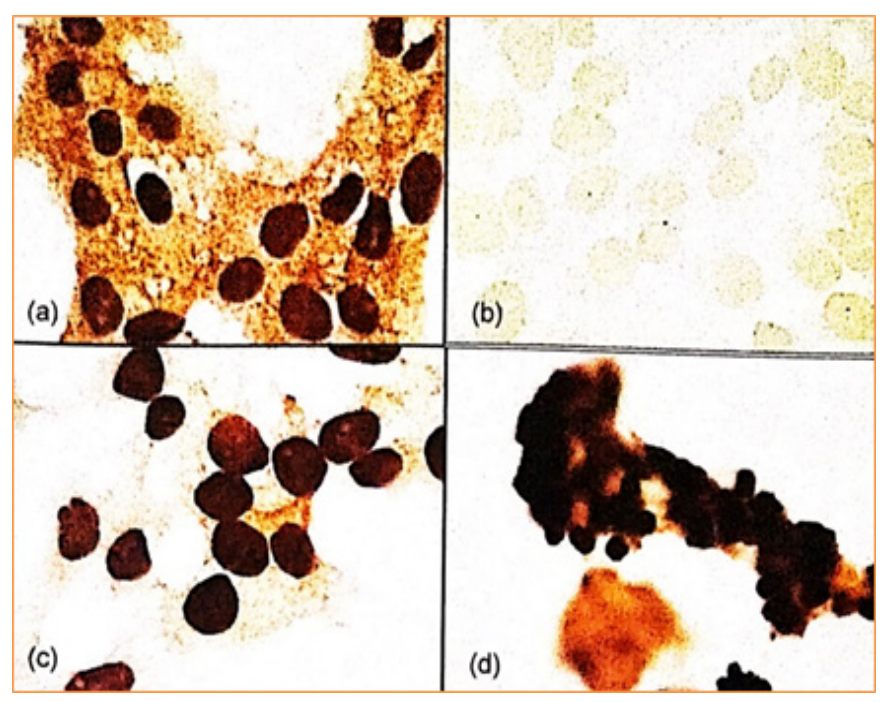

Fig. 3. HepG2 Cells Treated with (a) DNAse as a positive control, (b) 1\% DMSO as a negative control, (c) Xylocarpus moluccensis leaf diethyl ether extract (d) Xylocarpus granatum bark methanol extract after $24 \mathrm{hr}$ incubation. The cells were observed under a light microscope using 100x magnification.

Xylocarpus moluccensis leaf extract shows the highest cytotoxicity effects with the $\mathrm{IC}_{50}$ value of $25.12 \mu \mathrm{g} / \mathrm{ml}$. However, Xylocarpus moluccensis bark extract did not show any cytotoxicity effect on HepG2 cell line since the $\mathrm{IC}_{50}$ value produced by this extract was. above 30 $\mu \mathrm{g} / \mathrm{ml}(74.13 \mu \mathrm{g} / \mathrm{ml})$. Similarly, In our previous study, Xylocarpus granatum (bark) produced Cytotoxicity less than $30 \mu \mathrm{g} / \mathrm{ml}$ (Chaudhry et al., 2020c). Table 1 summarises the $\mathrm{IC}_{50}$ values of methanol extracts and leaf partition extracts. According to the previous report (Geran et al., 1972), the extract is categorized as cytotoxic against cancer cell line when the value of $\mathrm{IC}_{50}$ after 72 hours of incubation is lower the $30 \mu \mathrm{g} / \mathrm{ml}$. Based on this criterion, Xylocarpus moluccensis diethyl ether (leaf) extract selected for further cell death mechanism investigation. Also, Xylocarpus granatum methanol (bark) extract mode of cell death (DNA fragmentation study) on the HepG2 cell line studied. The solvent partitioning also performed to separate the extracts compounds according to different polarities using diethyl ether, butanol, and water.

The partitioning of crude methanol extract from Xylocarpus moluccensis leaf produced the highest yield with $72.02 \%$ than to that of butanol (17.81\%) and aqueous fractions (5.88\%). Subsequently, all these extracts subjected to cytotoxicity assay. As shown in figure 2, diethyl ether extract produced a significant dosedependent cytotoxicity effect on HepG2 cell line at all concentrations after 72 hours of incubation. Interestingly, dose-dependent cytotoxicity activity was also present when the cells treated with the extract at $24 \mathrm{hr}, 48 \mathrm{hr}$ (data not shown). Interestingly, the significant increase in cell death as compared to untreated control was observed at concentrations $0.39 \mu \mathrm{g} / \mathrm{ml}$ and higher, and $0.10 \mu \mathrm{g} / \mathrm{ml}$ and higher, respectively. The IC50 value at 72 hours exerted by diethyl ether extract of Xylocarpus moluccensis leaf was $0.22 \mu \mathrm{g} / \mathrm{ml}$, which was more cytotoxic than to that of crude methanol extract. The diethyl ether extract also produced time-dependent cytotoxicity effect when incubated at 24,48 , and 72 hours with the $\mathrm{IC}_{50}$ values of $9.68 \mu \mathrm{g} / \mathrm{ml}$, $4.12 \mu \mathrm{g} / \mathrm{ml}$, and $0.22 \mu \mathrm{g} / \mathrm{ml}$, respectively. By contrast, butanol and aqueous extracts of Xylocarpus moluccensis leaf showed no cytotoxicity effect on HepG2 cells, of which no inhibition of more than $50 \%$ of the total cell population exhibited by both extracts. However, butanol extract produced a proliferating effect on HepG2 cells (Table 1). To further investigate the mode of cell death, DNA fragmentation, and caspases (apoptotic enzymes) study performed.

Induction of Apoptosis in HepG2 cells via DNA fragmentation (Hallmark of apoptosis)

As explained above, the crude methanol extracts of Xylocarpus moluccensis leaf and Xylocarpus granatum bark produced a significant cytotoxicity effect with an $\mathrm{IC}_{50}$ value of 25.12 and $29.51 \mu \mathrm{g} / \mathrm{ml}$, respectively. Apoptosis mode of cell death determined by observing the nuclear DNA fragmentation. DNAse, I was used as a positive control to detect the sensitivity and reliability of the modified TUNEL assay. The final concentration of $1 \%(\mathrm{v} / \mathrm{v})$ DMSO used as negative control. Interestingly, darkly stained nuclei also observed in cells treated with the $\mathrm{IC}_{50}$ concentration of Xylocarpus moluccensis (leaf) and Xylocarpus granatum bark methanol extracts for 24 hours (Figure 3 (c) and (d)). Thus, indicating that apoptosis was the mode of cell death exerted by both of these extracts in mediating the cell death of HepG2 cell line. In our previous study, Xylocarpus moluccensis leaf diethyl ether extract also exhibited cell death via apoptosis, as indicated by distinct nuclei staining that was present after HepG2 cells treated with the $\mathrm{IC}_{50}$ concentration of 72 hours for 24 hours (Chaudhry et al., 2020c).

Extrinsic and Intrinsic pathways study via caspase 3/7, 8, and 9 activities in HepG2 cells

In this study, HepG2 cells treated with Xylocarpus moluccensis leaf diethyl ether extract at a concentration of $0.22 \mu \mathrm{g} / \mathrm{ml}$ over $30 \mathrm{hr}$. The levels of caspase- $3,-8$ and -9 were then determined by comparing the results to that of the untreated control. As shown in Figure 4, a significant increase in the expression of caspase- 8 was 
found in the HepG2 cell line when the cells treated with diethyl ether extract. The caspase- 8 activity significantly increased at $3 \mathrm{hr}$ to $21 \mathrm{hr}$ treatment. From $12 \mathrm{hr}$ to $15 \mathrm{hr}$, the level increased by 1.5 fold and gradually decreased again until $21 \mathrm{hr}$. HepG2 cells treated with diethyl ether extract also subjected to caspase- 9 protein assay. However, there was no significant increase in the level of caspase- 9 activity. Caspase- 8 and -9 are activator caspases, while caspase- 3 is an effector caspase. Caspase- 8 involves in the extrinsic apoptosis pathway, while caspase- 9 involves in the intrinsic or mitochondria-mediated pathway (Gul-e-Saba et al., 2019; Elmore, 2007). Interestingly, the level of caspase- 3 was significantly increased at $21 \mathrm{hr}$ treatment by 1.30 fold and reached the highest level at $24 \mathrm{hr}$ which induced by two-fold and decreased after that at $27 \mathrm{hr}$ (1.45 fold) and 30 hour-treatment (1.48 fold). However, the level remained significantly higher than that of the untreated control.

\section{Thin-layer Chromatography}

Xylocarpus moluccensis leaf diethyl ether, butanol, and aqueous extracts were subjected to Thin Layer Chromatography (TLC) to determine their chemical profiles. TLC was used to separate the compounds present in the extracts, according to their polarities. The extracts spotted on the TLC plates were developed in the solvent system, hexane: ethyl acetate: ethanol (6:3:1) for diethyl ether extract, methanol: water $(8: 2)$ for butanol extract and methanol: water (7:3) for aqueous extract. Long ultra-violet light visualization. The developed TLC plate for diethyl ether extract showed 11 fluorescence spots when exposed to long-wavelength UV light (UV365), with the $\mathrm{Rf}$ values of $0.07,0.15,0.23,0.27,0.32,0.35,0.44$, $0.50,0.63,0.78$ and 0.83 (Figure 5-A(1)). Butanol extract produced one spot with the Rf of 0.83 (Figure 5-B(1)), and two spots with Rf values of 0.80 and 0.91 observed for aqueous extract (Figure 5-C(1)). The developed TLC plate observed under short wavelength UV light (UV254) showed the separation of compounds. Dark spots against a yellow-green fluorescent background indicate the presence of a $\mathrm{C}=\mathrm{C}$ double bond. 5 spots observed for diethyl ether extract with the Rr values of $0.15,0.27,0.4$, 0.5 , and 0.83 (Figure 5-A(2)). Butanol extract (Figure 5 - $\mathrm{B}(2))$ showed only 1 spot $(\mathrm{Rf}=0.83)$ and 2 spots $(\mathrm{Rr}=0.8$ and 0.91 ) were observed for aqueous extract (Figure 5-C(2)). Furthermore, Vanillin-sulphuric acid spraying is a universal reagent, used for general detection of steroids, higher alcohols, phenols, and essential oils. The developed TLC plates were sprayed and heated, yielding colored spots. 4 spots observed for diethyl ether extract with the Rf values of $0.27,0.40,0.50$, and 0.63 (Figure $5-\mathrm{A}(3)$ ). No staining observed for butanol and aqueous extracts (Figure 5-B(3)) and (Figure 5-C(3)). The complete results obtained from TLC profiling show that at least 11 compounds were present in the diethyl ether extract, 1 in butanol extract, and 2 in the aqueous extract. However, our previous study Chaudhry et al., (2020c), confirms the presence of Flavonoid, steroid, terpenoid, phenols, tannins, glycoside, and saponin in extract of Xylocarpus moluccensis.

\section{Discussion}

Studies on the identification and development of new chemotherapeutic agents are essential for searching for effective drugs that kill cancer cells while leaving minimal side effects to the surrounding healthy tissues during cancer therapy. Apoptosis is the crucial mechanism to regulate the survival and death process of cells in cancer disease. Deregulation in the process of apoptosis stimulates cellular multiplication, which leads to the tumor and eventually metastasis and is a significant hurdle to effective cancer treatment (Jan and Chaudhry, 2019; Onyeagucha et al., 2017; Hassan et al., 2014). The plant kingdom provides enormous sources for natural cancer-combating agents. Vinblastine, vincristine, and paclitaxel are some of the plant-derived anticancer compounds that are clinically being used (Cragg et al., 2005). Mangrove plants are rich in bio-prospect potentials due to the presence of valuable proteins and secondary metabolites to survive extreme coastal conditions such as high salinity and flooding (Das, 2015). Mangroves have known to possess many ethnopharmacological benefits to treat a variety of diseases such as diarrhea, inflammation, diabetes, and cancer (Bandaranayake, 2002). Various studies also demonstrated the cytotoxicity effects of extracts prepared from this plant. Previously study reported a crude extract of Xylocatpus moluccensis exhibited cytotoxicity activity towards brine shrimp nauplii (Mondal et al., 2008). The Isoazadironolide and turrapubesin E compounds isolated from this plant showed antiproliferative activity against lymphocytic leukemia cell line (P388) (Tan and Luo, 2011).

Interestingly, for the partitioned extracts, Xylocatpus moluccensis diethyl ether showed higher Cytotoxicity than to that of the crude extract. In contrast, the butanol extract exhibited proliferating effect, and aqueous extract produced no changes. It is interesting to suggest that compounds that exert high cytotoxicity effects on liver cells were present in diethyl ether extract. However, certain compounds that produced antagonistic interaction (cell inhibitive and proliferative) and masked each other's activities were present in the crude extract and thus, may be responsible for exhibiting lower cytotoxicity effects compared to diethyl ether extract.

Induction of apoptosis is an opportunity for selective clinical intervention to bring about the death of the tumor cell without causing toxicity to healthy cells and adverse side effects (Kasibhatla and Tseng, 2003). In this study, the mode of cell death via apoptosis in liver cells induced by the prepared extracts was detected by DNA fragmentation using the TUNEL assay staining method. In TUNEL assay, 3'-hydroxyl termini of DNA ends labeled and stained (Kyrylkova et al., 2012), resulting in observable coloration on the nucleus of apoptotic cells. The presence of dark-stained nuclei observed in HepG2 cells that treated with the crude methanol and diethyl ether extracts of $X$. moluccensis leaf. Thus, it strongly suggests that the selected extracts exhibited cytotoxicity effects on HepG2 cells via apoptosis. Although various studies demonstrated cytotoxicity effects of the extracts or isolated compounds from this species, information on 
the cell death mechanism is extremely limited. However, there were reports on investigating the mode of cell death exerted by different species under the same Xylocarpus genus. A tetranortriterpenoid compound isolated from the Meliaceae plant family found to induce apoptosis in a cervical cancer cell line (HeLa-PRB) (Patwardhan et al., 2013). Limonoid isolated Trichilia rubescens inhibited human hepatocellular carcinoma cell (HepG2) growth by induction of apoptosis (Lange et al., 2016).

Caspases are essential as they are both the initiators and executioners to the mechanism of apoptosis (Wong, 2011). In this study, only diethyl ether extract of Xylocarpus moluccensis leaf selected for the investigation of caspase activation it produced strong cytotoxicity effect and apoptosis mode of death in HepG2 cells. Only the activity of caspase- 8 and -3 recorded, but activation of caspase- 9 was not detected. Therefore, the cell death exerted by the extract on the HepG2 cell line was via the extrinsic pathway or receptor-mediated pathway alone and independent of the mitochondrial-mediated pathway (intrinsic pathway). This mode of apoptosis pathway is almost similar to a previous study reported (Bush et al., 2001), where it showed that curcumin-induced apoptosis in human melanoma cell lines by activation of caspases-3 and -8 but not caspase- 9 . According to Porter and Janick (1999), pathways to caspase-3 activation can be either dependent on or independent of caspase- 9 function. The extrinsic pathway to caspase activation begins when death ligands, such as TNF and Fas ligand (FasL), bind to their death receptor, type 1 TNF receptor (TNF-R1) and a related protein called Fas (CD95), respectively (Wong, 2011; Hengartner, 2000). TNF-R1 and the Fas receptors have an intracellular death domain that selectively recruits adapter proteins. Binding of the death ligand to death receptor forms a ligand-receptor-adaptor protein complex, known as death-inducing signaling complex (DISC), which is responsible as a binding site for an adaptor protein (O'Brien and Kirby, 2008). Subsequently, DISC assembles and activates pro-caspase 8 to release the active initiator caspase, caspase- 8 , which starts apoptosis by cleaving other downstream or executioner caspases such as caspase-3 (Karp, 2008). In apoptotic cells, activated caspase-3 cleaves ICAD (CAD inhibitor) to release CAD (caspase-activated deoxyribonuclease) (Sakahira et al., 1998). The CAD subsequently degrades chromosomal DNA within the nuclei and causes chromatin condensation (Elmor, 2007), which observed in this study during TUNEL assay. The active compounds in the diethyl ether Xylocarpus moluccensis leaf extract act as a ligand to death receptors to induce the activation of caspase- 8 and eventually caspase- 3 , which in turn, triggers the activity of endonuclease to cleave genomic DNA and subsequently leads to the cell death via apoptosis in HepG2 cell line. However, there is minimal information on the cell death pathway induced by this plant from previous studies. In previous studies, most of the cytotoxic compounds isolated from Xylocarpus moluccensis were from seeds, and lack of information on Cytotoxicity of leaf part on any cancer cell line. Some of the limonoids isolated from genus Xylocarpus plants exhibit significant Cytotoxicity against cancer cells (Shen et al., 2009; Wu et al., 2010).
Tirucallane terpenoids isolated from stems of Picrasma quassinoids exhibited Cytotoxicity against gastric cancer cell line (MKN-28) via apoptosis, by activating caspase-3 and -9. Steroids from the bark of Aglaia argentea (Meliaceae) found to be cytotoxic against P-388 murine leukemia cells (Farabi et al., 2017). Phenol-rich mangrove plant, Avicennia marina (leaf ethyl acetate) extract showed Cytotoxicity and induced apoptosis in human breast cancer (AU565 and BT483) and liver cancer cells (HepG2 and Huh7) (Huang et al., 2016). Similarly, Cerbera odollam seeds exhibited cytotoxic activities against oral human epidermoid carcinoma (KB), human breast cancer cell (BC), and human small cell lung cancer (NCI-H187) (Laphookhieo et al., 2004). From this study, the diethyl ether extract prepared from Xylocarpus moluccensis possessed the potential to be subjected to study further and developed as chemotherapeutic agents in the treatment of liver cancer.

In conclusion, the Cytotoxicity and mechanisms of cell death induced by the Xylocarpus moluccensis extracts on HepG2 were studied. The leaf methanol extract of Xylocarpus moluccensis found to be cytotoxic against HepG2. The extracts were confirmed to induce cell death via the mechanism of apoptosis. The solvent partitioning study showed that Xylocarpus moluccensis (diethyl ether) extract showed higher Cytotoxicity than to that of the crude extract and was confirmed to induce cell death via apoptosis. The activity of caspase- 8 and -3 recorded, but the activation of caspase- 9 was not detected. Therefore, the cell death exerted by the extract on the HepG2 cell line was via an extrinsic pathway and independent of the intrinsic pathway. The presence of bio-active compounds, flavonoids, terpenoids, and other compounds present in the extract prepared from Xylocarpus moluccensis leaf has potential active metabolites of future cancer therapeutics.

\section{Acknowledgments}

This research work supported by Strategic Research Grant, Universiti Malaysia Terengganu (Vot No. 55197).

\section{Conflict of Interest}

The authors declare that there is no conflict of interest associated with the manuscript.

\section{References}

Bandaranayake WM (2002). Bioactivities, bioactive compounds, and chemical constituents of mangrove plants. Wetl Ecol Manag, 10, 421-52.

Bush JA, Cheung KJJ, Li G (2001). Curcumin induces apoptosis in human melanoma cells through a fas receptor/caspase-8 pathway independent of p53. Exp Cell Res, 271, 305-14.

Chaudhry GS, Jan R, Habsah M, Mohammad TST (2019a). Vitex rotundifolia fractions induce apoptosis in the human breast cancer cell line, MCF-7, via extrinsic and intrinsic pathways. Res Pharma Sci, 14, 273-85.

Chaudhry GS, Jan R, Zafar MN, Habsah M, Muhammad TST (2019b). Vitex rotundifolia fractions induced apoptosis in human breast cancer T-47D cell line via activation of extrinsic and intrinsic pathway. Asian Pac J Cancer Prev, 20, 3555-62. 
Chaudhry GS, Murni NIK, Zafar MN, et al (2020a). Induction of apoptosis by Stichopus chloronotus and Holothuria nobilis fractions in human cervical cancer cell line, HeLa. Int J Res Pharm Sci, 11, 1238-47.

Chaudhry GS, Abdah A, Zafar MN, et al (2020b). Induction of Apoptosis and role of PTX loaded HA-crosslinked nanoparticle in the regulation of AKT and RhoA. $J A d v$ Pharm Technol Res. In press

Chaudhry GS, Khairina NAS, Habsah M, et al (2020c). Induction of apoptosis by selected Xylocarpus sp., fractions in the human cervical cancer cell line, HeLa. Int J Res Pharm Sci, 11, 2332-9.

Cragg GM, Newman DJ (2005). Plants as a source of anticancer agents. $J$ Ethnopharm, 100, 72-9.

Das G, Gouda S, Mohanta YK, Patra JK (2015). Mangrove plants: A potential source for anticancer drugs. Indian $J$ Mar Sci, 44, 666-72.

Desai AG, Qazi GN, Ganju RK, et al (2008). Medicinal plants and cancer chemoprevention. Curr Drug Metab, 9, 581-91.

Elmore S (2007). Apoptosis: A review of programmed cell death. Toxicol Pathol, 35, 495-516.

Farabi K, Harneti D, Nurlelasari, et al (2017). Cytotoxic Steroids from the Bark of Aglaia argentea (Meliaceae). CMU J Nat Sci, 16, 293-306.

Ferlay J, Soerjomataram I, Ervik M, Dikshit R, Eser S, et al (2015). Cancer incidence and mortality worldwide: sources, methods and major patterns in GLOBOCAN 2012. Int $J$ Cancer, 136, 359-86.

Fuchs Y, Steller H (2011). Programmed cell death in animal development and disease. Cell, 147, 742-58.

Geran RI, Greenberg NH, Macdonald MM, Schumacher AM, Abbott BJ (1972). Protocols for screening chemical agents and natural products against animal tumors and other biological systems. Cancer Chemother Rep, 3, 59-61.

Gul-e-Saba C, Murni NIK, Ismail M, et al (2018). Induction of apoptosis by Aaptos sp., fractions in human breast cancer. Int J Res Pharm Sci, 9, 237-328.

Hassan M, Watari H, Abu-Almaaty A, Ohba Y, Sakuragi N (2014). Apoptosis and molecular targeting therapy in cancer. Biomed Res Int, 2014, 150845.

Hengartner MO (2000). Apoptosis: corralling the corpses. Cell, 104, 325-8.

Huang C, Lu CK, Tu MC, et al (2016). Polyphenol-rich Avicennia marina leaf extracts induce apoptosis in human breast and liver cancer cells and in a nude mouse xenograft model. Oncotarget, 7, 35874-93.

Hudaya T, Gul-e-Saba C, Taib M, Ismail N, Mohammad TST (2017). Methanol extracts of four selected marine sponges induce apoptosis in human breast cancer cell line, MCF-7. Int J Res Pharm Sci, 8, 667-75.

Jan R, Chaudhry GS (2019). Understanding apoptosis and apoptotic pathways targeted cancer therapeutics. Adv Pharm Bull, 9, 205-18.

Kalogeris T, Baines CP, Krenz M, Korthuis RJ (2012). Cell biology of ischemia/reperfusion injury. Int Rev Cell Mol Bio, 298, 229-317.

Karp G (2008). Cell and: molecular biology: Concepts and experiments. pp 653-657, John New Jersey: Wiley and Sons.

Kasibhatla S, Tseng B (2003). Why target apoptosis in cancer treatment?. Mol Cancer Therapeutic, 2, 573-80.

Kleinsmith LJ (2007). Principles of Cancer Biology, 4th ed. Pearson Benjamin Cummings in San Francisco; pp 312.

Kyrylkova K, Kyryachenko S, Leid M, Kioussi C (2012). Detection of Apoptosis by TUNEL Assay In Odontogenesis. Methods in Molecular Biology (Methods and Protocols) vol 887, ed. Kioussi C 41-47 USA: Humana Press.

Lange N, Tontsa AT, Wegscheid C, et al (2016). The Limonoids
TS3 and Rubescin E Induce Apoptosis in Human Hepatoma Cell Lines and Interfere with NF-KB Signaling. PLoS One, 11,8 .

Laphookhieo S, Cheenpracha S, Karalai C, et al (2004). Cytotoxic cardenolide glycoside from the seeds of Cerbera odollam. Phytochemistry, 65, 507- 10.

Li J, Yuan J (2008). Caspases in apoptosis and beyond. Oncogene, 27, 6194-6206.

Mahar J, Saeed A, Chaudhry GS, et al (2019). Synthesis, characterization and cytotoxic studies of novel 1,2,4-triazoleazomethine conjugates. J Iran Chem Soc, 17, 943-51.

Mondal S, Paul SK, Uddin SJ, et al (2008). A comparative study on the in vitro antibacterial activity of the pneumatophores of Heritiera fomes and Xylocarpus moluccensis. Ars Pharm, $49,51$.

Mou X, Kesari S, Wen PY, Huang X (2011). Crude drugs as anticancer agents. Int J Clin Exp Med, 4, 17-25.

Mukhopadhyay S, Panda PK, Sinha N, Das DN, Bhutia SK (2014). Autophagy and apoptosis: where do they meet? Apoptosis, 19, 555-66.

Nikoletopoulou V, Markaki M, Palikaras K, Tavernarakis N (2013). Crosstalk between apoptosis, necrosis and autophagy. Biochim Bio Acta Mol Cell Res, 1833, 3448-59.

Nithya M, Ambikapathy V, Panneerselvam A, Thajuddin, N (2014). Anti-tumor activity of different extracts of Ganoderma lucidum. World J Pharm Res, 3, 2204-14.

O'Brien MA, Kirby R (2008). Apoptosis: a review of pro-apoptotic and anti- apoptotic pathways and dysregulation in disease. $J$ Vet Emerg Crit Care, 18, 572-85.

Onyeagucha B, Subbarayalu P, Abdelfattah N, et al (2017). Novel post-transcriptional and post-translational regulation of pro-apoptotic protein BOK and anti-apoptotic protein Mcl-1 determine the fate of breast cancer cells to survive or die. Oncotarget, 8, 85984-96.

Patwardhan CA, Faug A, Peterson LB, et al (2013). Gedunin Inactivates the Co-chaperone $\mathrm{p} 23$ protein causing cancer cell death by apoptosis. J Biol Chem, 288, 7313-25.

Porter AG, Janick RU (1999). Emerging roles of caspase-3 in apoptosis. Cell Death Different, 6, 99-104.

Sakahira H, Enari M, Nagata S (1998). Cleavage of CAD inhibitor in CAD activation and DNA degradation during apoptosis. Nature, 391, 96-99.

Shen LR, Guo D, Yu YM, et al (2009). Chemical Constituents of Plants from the Genus Xylocarpus. Chem Biodiversity, 6, 1293-1308.

Simlai A, Roy A (2013). Biological activities and chemical constituents of some mangrove species from Sundarban estuary: An overview. Pharmacogn Rev, 7, 170-8.

Tan QG, Luo XD (2011). Meliaceous Limonoids: Chemistry and Biological Activities. Chem Rev, 111, 7437-7522.

Uddin SJ, Grice I, Tiralongo E (2011). Cytotoxic effects of Bangladeshi medicinal plant extracts. Evid-Based Complementary Altern Med, 7, 578092.

Uddin SJ, Nahar L, Shilpi JA, et al (2007). Gedunina limonoid from Xylocarpus granatum, inhibits the growth of $\mathrm{CaCo}-2$ colon cancer cell line In Vitro. Phytother Res, 21, 757-61.

Valli M, Pivatto M, Danuello A, et al (2012). Tropical biodiversity: has it been a potential source of secondary metabolites useful for medicinal chemistry?. Quím Nova, 35, 2278-87.

Wangensteen H, Duong GM, Alamgir M, et al (2006). Biological activities of limonoids, catechins, procyanidins, and extracts from Xylocarpus granatum. Nat Prod Commun, 1, 985-90.

Wong, RSY (2011). Apoptosis in cancer: from pathogenesis to treatment. J Exp Clin Cancer Res, 30, 87.

Wu J, Yang SX, Li MY, et al (2010). Limonoids and tirucallane derivatives from the seeds of a Krishna Mangrove, 
Gul-e-Saba Chaudhry et al

Xylocarpus moluccensis. J Nat Prod, 73, 644-9.

Zafar MN, Masood S, Chaudhry GS, et al (2019). Dalton Trans, 48, 15408-18.

\section{(c) (i) (8)}

This work is licensed under a Creative Commons AttributionNon Commercial 4.0 International License. 